\title{
A Study on the Relationship between Ethical Climate Perception and Innovative Work Behavior in Health Workers ${ }^{1}$
}

\author{
Assoc. Prof. Dr. Mutlu TOKMAK ${ }^{2}$
}

Submitted by: 03.12.2019

Accepted by: 06.07.2020

Article Type: Research Article

\begin{abstract}
This study aims to reveal the relationship between ethical climate perception and the innovative work behaviors of health workers. Besides, the effects of ethical climate perception sub-dimensions on innovative work behavior were tried to be introduced in the study. In order to realize the objectives determined in the study, field research was conducted in a public hospital in Ankara. 280 public health workers participated in the study. The data obtained from the research were subjected to descriptive statistics analysis, correlation analysis, and multiple linear regression analysis. According to the results of the analysis, it is determined that there is a $21 \%$ statistically significant and positive relationship between the ethical climate perception and innovative working behavior levels of healthcare workers. Among the ethical climate perception sub-dimensions, benevolence and independence dimensions were found to be positively related to innovative work behavior. A 10 percent deviation in the innovative work behaviors of health workers is explained by ethical climate perception sub-dimensions. It was concluded that "benevolence" and "independence", the ethical climate sub-dimensions, affected the innovative working behavior by $17 \%$ and $23 \%$, respectively. On the other hand, "laws, and codes", "rules", and "instrumental" dimensions were not found to have a statistically significant effect.
\end{abstract}

Anahtar Kelimeler: Ethical Climate Perception, Innovative Work Behavior, Health Workers

Atıf: Tokmak, M. (2020). A study on the relationship between ethical climate perception and innovative work behavior in health workers. Anadolu University Journal of Social Sciences, 20(4), 51-64.

\footnotetext{
${ }^{1}$ Since the article was submitted for publication in the previous year, ethics committee approval is not required.

${ }^{2}$ Gendarmerie and Coast Guard Academy Department of Social Sciences, mutlu-tokmak@hotmail.com, ORCID: 0000000274281322
} 


\title{
Sağlık Çalışanlarında Etik İklim Algısı ve Yenilikçi Çalışma Davranışı ilişkisine Yönelik Bir Araştırma
}

\author{
Doç. Dr. Mutlu TOKMAK
}

\section{Öz}

Bu çalışmanın amacı, sağlık çalışanlarının etik iklim algısı ile yenilikçi çalışma davranışı düzeyi arasındaki ilişkiyi ortaya koymaktır. Ayrıca etik iklim algısı alt boyutlarının yenilikçi çalışma davranışı üzerindeki etkisi de ortaya konmaya çalışılmaktadır. Araştırmada belirlenen amaçları gerçekleştirmek için Ankara ilinde faaliyet gösteren bir kamu hastanesinde alan araştırması gerçekleştirilmiştir. Araştırmaya 280 kamu sağlık çalışanı katılmıştır. Araştırma neticesinde elde edilen veriler, tanımlayıcı istatistik analizi, korelâsyon analizi ve çoklu doğrusal regresyon analizine tâbi tutulmuştur. Analiz sonuçlarına göre, sağlık çalışanlarının etik iklim algısı ile yenilikçi çalışma davranışı düzeyleri arasında istatistiksel olarak anlamlı ve pozitifyönde yaklaşık \%21 oranında ilişki olduğu belirlenmiştir. Etik iklim algısı alt boyutlarından başkalarının iyiliğini isteme ve bağımsızlık boyutlarının pozitif yönde yenilikçi çalışma davranışı ile ilişkili olduğu tespit edilmiştir. Sağlık çalışanlarının yenilikçi çalışma davranışlarının etik iklim algısı alt boyutları ile açıklanma oranı 0.10'dur. Etik iklim alt boyutlarından başkalarının iyiliğini isteme boyutunun yaklaşık \%17 oranında, bağımsızlık boyutunun ise yaklaşık \%23 oranında yenilikçi çalışma davranışını etkilediği sonucuna ulaşılmıştır.

Anahtar Kelimeler: Anahtar Kelimeler: Etik İklim Algısı, Yenilikçi Çalışma Davranışı, Sağlık Çalışanları 


\section{Introduction}

With developing technology, the competition between the companies is increasing. It is not possible for enterprises that cannot offer new products and services to their customers to survive in an increasingly competitive environment. Technology brings change together. It is unlikely that businesses that are resistant to change will be able to survive. In order for the change in the enterprises to be essential, it must be supported by the employees. The ability of the employees to keep up with the changes within the enterprise will increase their contribution to the enterprises in the provision of new products and services.

The ethical climate is considered as the rules and norms that determine the ethical practices within the enterprise. Ethical climate perception is seen as a set of values that lead the way for the employees in the enterprise and guide them about which behaviors are correct and which are wrong. Employees in enterprises with a high level of ethical climate perception adapt to act within the framework of moral rules in order to improve themselves, their colleagues and the institution they work for.

In this study, the relationship between ethical climate perception and the innovative work behavior of health workers is examined. Besides, the effect of ethical climate perception sub-dimensions on innovative work behavior has been tried to be revealed with the research. For this purpose, data were obtained from a public hospital staff working in Ankara using the questionnaire method.

\section{Conceptual Framework}

\section{Ethical Climate Perception}

The concept of ethics is defined as the set of values that form the basis of moral rules, standards and behavioral patterns (Tsalikis and Fritzsche, 2013, p. 337). In another definition, ethics is defined as a systematic effort to reveal the rules about people's management, the values to be considered, and the characteristics of accepted characters (Sabuncuoğlu, 2009, p. 367). According to Sökmen (2016, p. 20), ethics is defined as "a set of moral principles that guide the behavior of individuals or groups at individual, professional, managerial and organizational levels and establish good or bad, right or wrong standards of choice of them". In order to evaluate an action and thought ethically, it is thought that there should not be any expectation of benefit and interest, that it does not have any intentions, that there is no concern about getting punished and that it should not be connected to reasons such as obeying the laws (Aktaş, 2014, p. 23). The concept of ethics is considered as a subset of the working atmosphere from an organizational perspective.

The ethical climate is to treat the organizational practices within the enterprise in terms of their moral dimensions. The initiation of ethical behaviors within the enterprise is possible only by the acceptance of the predetermined norms and rules by the employees and believing in these rules. (Cullen, Parboteeahand, Victor, 2003, p. 128). The ethical climate is defined as the perception of organizational practices and rules with ethical content (Victor and Cullen, 1988, p. 101). Thanks to the ethical climate within the organization, employees consider alternative solutions in order to solve the problems they face. The ethical climate serves as a reference for employees to determine which behaviors are acceptable and which are unacceptable. and helps them to make more accurate decisions (Barnett and Schubert, 2002, p. 281). According to Yurdakul (2013, p. 281), the ethical climate is the set of principles and standards that guide the employees in an organization in terms of correct behaviors. In fact, it is institutionalized practices in the organization that reveal what is accepted as right and wrong.

In the studies on ethical climate, it is seen that the five dimensions of ethical climate are benevolence, laws and codes, rules, instrumental, and independence. It is possible to explain these dimensions briefly as follows (Martin \& Cullen, 2006, p. 178-179; Yeşil, Mavi \& Ceylan, 2017, p. 23-24): 
Benevolence: In this ethical climate dimension, there is a sincere demand for the well-being of others. This dimension is based on the utilitarian theory of moral philosophy. Friendship and team spirit are at the forefront, and they include practices supported by managers who want and care for the well-being of others (Torun, 2013, p. 45). The most important thing is to show courtesy to colleagues in the dimension of benevolence. Employees want the best of their friends inside and outside the organization. In the researches, it is seen that this climate type is the one that is mostly applied by the employees (Karadut, 2014, p. 15).

Laws and Codes: In this climate dimension, except for the laws and codes of conduct established by the organization, the perception that the decision-making is supported based on the rules coming from external sources is prioritized (Torun, 2013, p. 45). Employees must follow the ethical codes and instructions of their profession. Employees must make decisions based on rules from outside the organization, such as laws. Organizations governed by laws and codes are based on the standards and principles established outside the organization when making decisions. Laws and codes are related to codes of conduct adopted by the external environment within the ethical criteria of being principled (Yağmur, 2013, p. 26).

Rules: This dimension is related to the rules determined and adopted by the organization. Decisions taken within the organization are established according to local rules and standards. In the rules dimension, the ethical criteria of being principled are focused (Yağmur, 2013, p. 27). In this climate type, individuals should act according to the rules and determined principles while making ethical decisions. Employees in the rules dimension are expected to fully comply with the rules and norms set by the organization. In this dimension, the ethical criterion of being principled and the focus of organizational analysis are emphasized (Ögüt \& Kaplan, 2011, p. 195).

Instrumental: In this dimension, personal interests are prioritized. It is the type of ethical climate in which individuals behave according to their personal interests in their decisions. Employees who adopt this climate type act with the idea that they behave egoistically while making ethical decisions in their institution (Ögüt \& Kaplan, 2011, p. 195). The instrumental dimension includes egoism criteria and levels of personal and organizational focus (Yağmur, 2013, p. 27). Within this framework, the employees strive to achieve better for themselves as well as striving for the organization to gain more. Here, the interests of individuals rather than the interests of the majority are prioritized (Karadut, 2014, p. 16).

Independence: Employees behave according to their own moral beliefs within the framework of pre-determined principles. When taking their decisions, they take individual decisions by considering moral criteria (Yağmur, 2013, p. 27). In the dimension of independence, it is possible for the employees to direct their behaviors within the framework of their moral beliefs. In making ethical climate decisions, individual moral beliefs are prioritized. The basic element that employees rely on when making decisions is their own principles rather than external factors (Özyer, 2010, p. 24).

\section{Innovative Work Behavior}

The dictionary meaning of innovation is defined as "developing new approaches in design, production or product marketing to gain an advantage over competitors or to be innovative" (Dictionary Of Business, 2002, p. 266). In general, the word innovation is used in the sense of designing new services or products and developing new production and presentation methods (Kılıç \& Keklik, 2012, p. 90).

Innovative work behavior is defined as the conscious introduction and application of new ideas of products, processes, and procedures to the work, department or the whole organization by the employees (West, 2002, p. 357). According to De Jong (2006, p. 19), innovative work behavior is defined as the behaviors of employees to initiate and promote new and useful ideas, processes, products or procedures within a business role, group or organization. Innovative work behavior is seen as a multistage process in which an employee identifies a problem and then generates new ideas about it, eventually developing a suitable model to use and benefit from 
(Wojtczuk-Turek, 2012, p. 73). Lukes and Stephan (2017, p. 137) define innovative work behavior as the behaviors of employees to put forward new ideas and then try to implement them.

Organizations need to create better and new processes and take advantage of the innovative potential of employees in order to struggle in a highly dynamic and competitive business environment. In academic studies, it has been concluded that innovative behaviors of employees help in achieving organizational success (Unsworth \& Parker, 2003, p. 175; Van de Ven, 1986, p. 590; Amabile, Barsade, Mueller \& Staw, 2005, p. 367).

The processes followed by employees to demonstrate innovative work behavior are expressed in four stages: opportunity exploration, idea generation, championing and application. These steps are briefly described as follows (De Jong and Den Hartog, 2010, p. 24; Radaelli, Lettieri, Mura \& Spiller, 2014, p. 401; Ramamoorthy, Flood, Slattery \& Sardessai, 2005, p. 142; Scoot and Bruce, 1994, p. 582; Ungureanu, Pop \& Ungureanu, 2016, p. 497; Thompson; and Akgemci, 2019, p. 1714):

Opportunity Exploration: This stage is the preliminary preparation of ideas (West, 2002, p. 357). Innovation begins with the discovery of an idea or the emergence of a problem. New problems bring innovative solutions in general (Drucker, 1998, p. 15).

Idea Generation: At this stage, innovative employees are looking for alternative solutions for how existing products, services, and processes can be improved. This stage may be related to new products, services or processes, entry of new markets, improvements in existing business processes, or solutions to generally defined problems (Van de Ven, 1986, p. 590).

Championing: After the formation of new ideas, the process of finding support from the organization for innovative work behavior starts (Kanter, 1988, p. 94). This stage includes the support of other organization members in order to realize the idea, forming coalitions with colleagues, excitement about innovation, trusting and believing that innovation will result in success, insisting on innovation and including the right people in the process. This stage is the most important stage in the development of innovative behaviors. Other colleagues or management convinced at this stage are mobilized to support the innovative idea (Jannsen, 2000, p. 289).

Application: At this stage, an important effort and result-oriented attitude is needed. Employees embody the idea or solution by producing a prototype or model that can be implemented. Innovative work results arise as a result of the stages of innovative behavior (Çapraz et al., 2014, p. 53). The implementation of the idea means that innovations become a regular part of the business processes (De Jong, 2008, p. 7).

\section{Literature Review and Research Hypotheses}

There are many studies in the literature on ethical climate perception. When the studies are examined, it is seen that the relationship and effects of ethical climate perception on many subjects such as organizational communication (Eyidoğan, 2013), organizational commitment (Bilgen, 2014; Eren and Hayatoğlu, 2011), ethical leadership (Yağmur, 2013), trust in manager (Eren and Hayatoğlu, 2011), work performance (Eren and Hayatoğlu, 2011), and job satisfaction (Cevgen and Üngüren, 2009; Kökalan and Şevik, 2019) are analyzed. In other studies, the relationships between ethical climate perception and demographic variables (Bilgen, 2014) and the comparison of private and public organizations in terms of ethical climate (Bilgen, 2014) were examined. In another study aimed at academic staff conducted by Torun (2013), the impact of ethical climate perception on trust in the institution is examined.

There are many studies in the literature on innovative work behavior. De Clercq, Dimov and Belausteguigoitia (2016) conducted a study to explain the innovative behavioral roles of employees regarding negative working conditions. Bani-Melhem, Zeffane and Albaity (2018) investigated the determinants of the employees' 
innovative behaviors and the effect of job satisfaction, support from colleagues and work stress on innovative behaviors of employees. Hrnjic, Pilav-Velic, Djidelija and Jahic (2018) aimed to investigate the effect of job satisfaction on innovative capacity building in the telecommunications sector by examining the effectiveness of human resource management practices in the innovation process. In their study, Chou, Huang and Lin (2018) investigated the effects of organizational intellectual capital on the innovative behaviors of front-office workers. Engelen, Weinekötter, Saeed and Enke (2018) examined the impact of corporate support programs on the innovative behaviors of employees in a cross-cultural manner.

In their research examining the relationship between ethical climate perception dimensions and business innovation, Neubaum, Mitchell and Schminke (2004) found a positive and strong relationship. In their study, West and Wallace (1991) and West and Anderson (1996) found that organizational climate perception dimensions positively affect the innovation behaviors of managers and employees. In his research on employees working in the aviation and aerospace industry, Akkoç (2012) found that ethical climate perception positively and significantly (80\%) influenced innovative work behavior.

The following hypotheses have been developed in accordance with the purpose of the research by examining the above studies.

Hypothesis 1: There is a positive relationship between the ethical climate perception (H1a: Benevolence, H1b: Laws and Codes, H1c: Rules, H1d: Instrumental, H1e: Independence) and innovative work behaviors of health workers.

Hypothesis 2: Ethical climate perception sub-dimensions of health workers (Benevolence, Laws and Codes, Rules, Instrumental, Independence) have an impact on their innovative work behaviors.

\section{Methodology}

\section{Aim and Method of Research}

The aim of this study is to reveal the relationship between health workers' ethical climate perceptions and innovative work behaviors. Besides, the effects of the dimensions of ethical climate perception, which include benevolence, the laws, and codes, rules, instrumental and independence, on innovative work behavior are examined. In order to realize the objectives determined in the study, field research was conducted. The survey method was used as the data collection technique in field research. IBM SPSS 25.0 package program was used to analyze the data obtained. In this study, descriptive statistical analysis was used to determine the opinions of employees about ethical climate perception and innovative behavior. Correlation analysis and multiple linear regression analyses were performed to evaluate the hypotheses determined in the study.

\section{Sample and Data Collection Tool}

In this study, a public hospital in Ankara was taken as a sample. A questionnaire was distributed to 300 health workers working in the hospital and 280 questionnaires were received due to workload. The questionnaire used in the research consists of three parts. The first part consists of the scale to determine the employees' ethical climate, the second part consists of the innovative behavior scale and the third part consists of demographic information.

Ethical Climate Perception Scale: "Ethical Climate Questionnaire (ECQ)" which was developed by Victor and Cullen (1988) was used to determine the ethical climate perceptions of the health workers participating in the study. The scale consists of 26 statements and five dimensions in the original. The dimensions in the original scale are named as benevolence (7 statements), laws and codes (4 statements), rules (4 statements), instrumental (7 statements) and independence (4 statements). The ethical climate scale used in the study was 
translated into Turkish by Biçer (2017) and its validity and reliability were tested. In this study, hypotheses were evaluated using the original scale dimensions.

Innovative Work Behavior Scale: The Innovative Work Behavior Scale (IWB) prepared by De Jong and Den Hartog (2008) was used to determine the level of innovative work behavior of the participants. The scale consists of 10 statements in the original and is evaluated as a single dimension. The scale was translated into Turkish by Biçer (2017) and its validity and reliability analyses were performed. In this study, the innovative behavior scale was used as one dimension in the evaluation of hypotheses.

5 -point Likert scale was used in the statements in both scales used in the study., where "1" and "5" stand for Strongly Disagree and Strongly Agree, respectively.

\section{Evaluation of Research Findings}

IBM SPSS 25. 0 statistical package program was used in the analysis of the questionnaires obtained and the $95 \%$ confidence interval was taken into consideration in the analysis of hypotheses.

\section{Demographic data}

280 health workers participated in the study. 120 (42.9\%) of the participants were male and 160 (57.1\%) were female. When age distributions were examined, it was seen that among the participants, 60 (21.4\%) people were aged 25 and under, 64 (22.9\%) people were between the ages of 26-31, 88 (31.4\%) people were between the ages of 32-37, 64 (22.9\%) people were between the ages of 38-43 people, and 4 (1.4\%) people were aged 44 and older. Of the participants, 244 (87.1\%) had a bachelor's degree and $36(12.9 \%)$ had a master's degree. When the marital status of the participants was examined, it was found that $160(57.1 \%)$ health workers were married and $120(42.9 \%)$ of them were single.

\section{Reliability analysis and descriptive statistics}

Descriptive statistics related to the scales used in the research are given in the tables below. The reliability value of the scale used to determine the ethical climate perception of the health workers participating in the research was 0.681 and the reliability value of the scale used to determine their opinions about innovative work behavior was 0.854 . Cronbach's Alpha value is reliable in the range of $0.60 \leq \alpha \leq 0.80$ and highly reliable in the range of $0.80 \leq \alpha \leq 1.00$ (Kalayc1, 2008, p. 405). The ethical climate perception scale was found to be reliable at the scales used in the research, where the innovative work behavior scale was found to be highly reliable.

Descriptive statistical results of the responses of the health workers participating in the study to determine the ethical climate perception are shown in the table below.

Table 1

Descriptive Statistics of Ethical Climate Perception Scale

\begin{tabular}{|l|c|c|c|}
\hline \multicolumn{1}{|c|}{ Ethical Climate Perception } & $\mathbf{N}$ & Mean & D.F \\
\hline Benevolence & 280 & 3.57 & .55 \\
\hline Laws and Codes & 280 & 3.69 & .70 \\
\hline Rules & 280 & 3.39 & .54 \\
\hline Instrumental & 280 & 2.87 & .63 \\
\hline Independence & 280 & 3.29 & .67 \\
\hline Ethical Climate Perception (Overall) & $\mathbf{2 8 0}$ & $\mathbf{3 . 3 3}$ & $\mathbf{. 3 3}$ \\
\hline
\end{tabular}

The general average level of participation of the participants in the statements aimed at determining the ethical climate perception is 3.33. As the statements in the study were evaluated according to the 5-point Likert scale, it was seen that the ethical climate perceptions of health workers were above the median value. When the 
average values of the ethical climate perception scale sub-dimensions were compared, it was found that the highest average was in the law and codes dimension.

Descriptive statistical data of the scale created to determine the levels of innovative work behavior of the health workers participating in the study are given in the table below.

Table 2

Descriptive Statistics of Innovative Work Behavior Scale

\begin{tabular}{|l|c|c|c|}
\hline \multicolumn{1}{|c|}{ Innovative Work Behavior } & N & Mean & D.F \\
\hline Innovative Work Behavior & 280 & $\mathbf{3 . 6 2}$ & $\mathbf{. 6 1}$ \\
\hline
\end{tabular}

The mean value of the scale used to determine the innovative work behavior levels of the participants is 3.62. As the statements in the study were evaluated according to the 5-point Likert scale, it was determined that the levels of innovative work behavior of health workers were above the median value.

\section{Testing research hypotheses}

Kolmogorov-Smirnov test was performed to determine the suitability of the data obtained for the study. It was determined that Kurtosis and Skewness values were between -1 and +1 values. Hair, Black, Babin, Anderson and Tatham (2013) state that when Kurtosis and Skewness values are in the range of -1 and +1 , analyzes can be made according to normal distribution.

Hypothesis 1: There is a positive relationship between the ethical climate perception of health workers (H1a: Benevolence, H1b: Laws and Codes, H1c: Rules, H1d: Instrumental, H1e: Independence) and innovative work behaviors.

Pearson correlation analysis was performed to determine the relationship between ethical climate perception and innovative work behaviors of the health workers participating in the study. The results of the analysis are given in the table below.

Table 3

Correlation Analysis for the Relationship Between Ethical Climate Perception and Innovative Work Behavior

\begin{tabular}{|l|l|}
\hline Correlation Analysis & Innovative Work Behavior \\
\hline Benevolence $(\mathrm{H} 1 \mathrm{a})$ & $\mathbf{. 1 7 7 ^ { * * }}$ \\
\hline Laws and Codes $(\mathrm{H} 1 \mathrm{~b})$ & .021 \\
\hline Rules $(\mathrm{H} 1 \mathrm{c})$ & .097 \\
\hline Instrumental $(\mathrm{H} 1 \mathrm{~d})$ & .021 \\
\hline Independence $(\mathrm{H} 1 \mathrm{e})$ & $\mathbf{. 2 9 1}$ \\
\hline Ethical Climate Perception $(\mathrm{H} 1)$ & $\mathbf{. 1 4}^{\star *}$ \\
\hline
\end{tabular}

It is found that there is a positive and significant relationship of $21.4 \%$ between ethical climate perceptions and innovative work behavior levels of the health workers participating in the study as a result of the correlation analysis conducted. Ethical climate perceptions of health workers increased their innovative work behavior levels by approximately $21 \%$. When the relationships between ethical climate perception sub-dimensions and innovative work behavior levels were examined, it was found that there was a positive and significant relationship between the innovative work behavior levels and the benevolence (17.7\%) and independence 
(27.7\%) sub-dimensions. No statistically significant relationship was found between the innovative working behavior levels and the laws and codes, rules, and instrumental sub-dimensions of ethical climate perception. As a result of correlation analysis, it is concluded that while H1, H1a, and H1e hypotheses are supported, H1b, H1c, and H1d hypotheses are not supported.

Hypothesis 2: Sub-dimensions of ethical climate perceptions of health workers (Benevolence, Laws, and Codes, Rules, Instrumental, and Independence) have an effect on innovative work behaviors.

Multiple linear regression analysis was conducted in order to determine the effect of the opinions of health workers on ethical working climate sub-dimensions on innovative working behavior. The results of the analysis are given in the table below.

Table 4

Multiple Linear Regression Analysis of the Effect of Ethical Climate Perception Dimensions on Innovative Working Behavior

\begin{tabular}{|c|c|c|c|c|c|c|}
\hline \multicolumn{7}{|c|}{ Dependent Variable: Innovative Work Behavior } \\
\hline $\begin{array}{l}\text { Independent Variables } \\
\text { (Ethical Climate Perception } \\
\text { Dimensions) }\end{array}$ & $\mathbf{R}^{2}$ & $\mathbf{F}$ & $\beta$ & $t$ & $\mathbf{p}$ & $\begin{array}{l}\text { Durbin } \\
\text { Watson }\end{array}$ \\
\hline Benevolence & \multirow{5}{*}{.102} & \multirow{5}{*}{$6.191^{* *}$} & .169 & 1.999 & $.047^{*}$ & \multirow{5}{*}{1.755} \\
\hline Laws and Codes & & & -.095 & -1.459 & .146 & \\
\hline Rules & & & .047 & .654 & .513 & \\
\hline Instrumental & & & .000 & .001 & 1.000 & \\
\hline Independence & & & .228 & 4.051 & $.000^{* *}$ & \\
\hline
\end{tabular}

According to the results of multiple linear regression analysis, the Durbin Watson test value was found to be 1.755 and no autocorrelation was found between the variables. Generally, a Durbin-Watson test value of 1.5 2.5 shows that there is no autocorrelation between the variables (Öztürk, 2006, p. 267). In the multiple linear regression model, which was created to determine the effect of ethical climate perception sub-dimensions on innovative work behavior, $\mathrm{R}^{2}$ value was found to be 0.102 . Approximately $10 \%$ of the innovative work behavior levels of employees can be explained by the ethical climate perception sub-dimensions. When beta values were examined, it was found that the dimension of benevolence from the ethical climate perception sub-dimensions positively affected the innovative working behavior by 0.169 percent and the independence dimension by 0.228 percent, while the other sub-dimensions did not have a statistically significant effect. It was found that Hypothesis 2 was supported within the framework of the multiple linear regression model in which the effects of ethical climate perception sub-dimensions on innovative work behavior were evaluated.

\section{Evaluation and Conclusion}

In this study, where the relationship between ethical climate perception and innovative work behaviors of health workers is examined, statistically significant results were obtained. As a result of the descriptive statistical analysis performed to determine the ethical climate perception of health workers, it was concluded that the ethical climate perception of the employees was slightly above the average value. Innovative work behaviors of health workers were found to be slightly above the average value as well. 
As a result of the correlation analysis that examined the relationship between ethical climate perception and innovative work behavior levels of health workers, it was found that there was a positive and significant relationship at approximately $21 \%$ level. It has been found that there is a relationship between innovative work behavior and the benevolence and independence sub-dimensions of the ethical climate perception at the rates of approximately $18 \%$ and $29 \%$, respectively. There was no statistically significant relationship between innovative work behavior and the laws and codes, rules, and instrumental sub-dimensions.

As a result of multiple regression analysis conducted to determine the effect of ethical climate perception subdimensions on the level of innovative work behavior, R2 value was found to be approximately $10 \%$. Approximately $10 \%$ of the deviation in the level of innovative work behavior can be explained by ethical climate perception. It was concluded that the sub-dimensions of benevolence and independence had an effect of about $17 \%$ and $23 \%$ on innovative work behavior, respectively.

It is clear that the ethical climate to be established in health institutions has an impact on the innovative behaviors of the employees. Innovative health care institutions that want to provide better service to their patients should strive to create an ethical climate in their hospitals. Ethical climate perception positively affects employees' perspectives on innovation.

It is possible to sort the suggestions regarding thr kind of applications that innovative health organizations should include in their hospitals while creating an ethic environment in terms of offering the patients better services (Tütüncü and Savran, 2007, p. 213-214; Büte, 2011, p. 188-189):

- Providing additional staff and equipment especially when the workflow is too much.

- Providing possibilities to the employees make to their decisions regarding their work, and allowing them to own their job with doing that action, and also increasing the personal success.

- Giving feedbacks in the form of appreciating the successes, rather than specifying the negativities.

- Increasing personal development and rest periods.

- Improving the quality communication.

- Motivating the employees with the in-service and out-service educations and preparing them to the new duties by avoiding routine.

- Rewarding ethical behaviors and creating a positive ethical environment in the workplace.

- Enhancing the sense of belonging by preventing the behaviors that disrupt the team spirit.

- Eliminating ethical uncertainties related to work and protecting the employees from the negative effects of stress within the job satisfaction that will be gained by the employee.

- Preventing the stress caused by the role uncertainty by creating the job definitions, these are the regulations that can be recommended in an administrative way in order to face less stress caused by business and organization.

As a suggestion for future studies, it is thought that researching other factors affecting innovative work behavior will contribute to both the scientific world and working life. 


\section{References}

Akkoç, İ. (2012). Gelişim kültürü ve etik iklimin yenilikçiliğe etkisinde dağıtım adaletinin rolü (The Effects of Development Culture and Ethical Climate on Innovative Behaviour: Mediating Role of Distributive Justice). Alanya İsletme Fakültesi Dergisi, 4(3). 45-60. Access address: http://www.acarindex.com/dosyalar/makale/acarindex-1423869054.pdf

Aktaş, K. (2014). Etik-ahlâk ilişkisi ve etiğin gelişim (Ethic-Moral Relationship and Ethic's Development Process). Uluslararası Yönetim ve Sosyal Araştırmalar Dergisi, 1(2), 22-32. Access address: http://www.uysad.com/FileUpload/as907385/File/kadir_aktas.pdf

Amabile, T. M., Barsade, S. G., Mueller, J. S., \& Staw, B. M. (2005). Affect and creativity at work. Administrative Science Quarterly, 50(3), 367-403. https://doi.org/10.2189/asqu.2005.50.3.367

Bani-Melhem, S., Zeffane, R., \& Albaity, M. (2018). Determinants of employees' innovative behavior. International Journal of Contemporary Hospitality Management, 30(3), 1601-1620. https://doi.org/10.1108/IJCHM-02-2017-0079

Barnett, T., \& Schubert, E. (2002). Perceptions of the ethical work climate and covenantal relationships. Journal of Business Ethics, 36(3), 279-290. https://doi.org/10.1023/A:1014042613106

Biçer, M. (2017). Etik iklim, örgütsel öğrenme ve yenilikçi davranış ilişkisi üzerine bir araştırma (A research on the relationship between ethical climate, organizational learning and innovative behavior). (Unpublished doctoral dissertation), Osmaniye Korkut Ata Üniversitesi, Osmaniye. Access address: https://tez.yok.gov.tr/

Bilgen, A. (2014). Çalışanların etik liderlik ve etik iklim algılamalarının örgütsel bağlllıklarına etkisi: özel ve kamu sektöründe karşılaştırmalı bir uygulama. (The effects of employees' perceptions of ethical leadership and ethical climate on the organizational commitment: A comparative application on the private and the public sectors). (Unpublished master's thesis), Bahçeşehir Üniversitesi, İstanbul. Access address: https://tez.yok.gov.tr/

Büte, M. Etik iklim, örgütsel güven ve bireysel performans arasındaki ilişki (Ethical climate, organizational trust and individual relationship between performance). Atatürk Üniversitesi İktisadi ve İdari Bilimler Dergisi, 25(1), 171-192. Access address:

Chou, C. Y., Huang, C. H., \& Lin, T. A. (2018). Organizational intellectual capital and its relation to frontline service employee innovative behavior: consumer value co-creation behavior as a moderator. Service Business, 12(4), 663-684. https://doi.org/10.1007/s11628-018-0387-4

Cullen, J. B., Parboteeah, K. P., \& Victor, B. (2003). The effects of ethical climates on organizational commitment: A two-study analysis. Journal of Business Ethics, 46(2), 127-141. https://doi.org/10.1023/A:1025089819456

Çapraz, B., Ünnü, N. A. A., İlic, D. K., Kocamaz, M., Çiçekli, U. G., Aracıoğlu, B. at al. (2014). Çalışanlar perspektifinden inovatif iş davranışının belirleyicileri: İzmir ilindeki öncelikli sektörlere ilişkin bir araştırma (Innovative Work Behavior Determinants from the Perspective of Employees: A Research on Prior Industries in Izmir). Girişimcilik ve İnovasyon Yönetimi Dergisi, 3(1), 49-72. Access address: http://betadergi.com/jeim/yonetim/icerik/makaleler/19-published.pdf

Çevirgen, A., \& Üngüren, E. (2009). Konaklama İşletmelerinde Etik İklim ve İş Tatmini İlişkisi (Between ethical climate and satısfaction in accommodation businesses relationship) 10. Ulusal Turizm Kongresi (21-24 Ekim 2009), 273-283. Access address: https://www.yyu.edu.tr/images/files/TURIZM_ETIGI.pdf 
De Clercq, D., Dimov, D., \& Belausteguigoitia, I. (2016). Perceptions of adverse work conditions and innovative behavior: The buffering roles of relational resources. Entrepreneurship Theory and Practice, 40(3), 515-542. https://doi.org/10.1111/etap.12121

De Jong, J. P., \& Den Hartog, D. (2010). Measuring innovative work behaviour. Creativity and innovation management, 19(1), 23-36. https://doi.org/10.1111/j.1467-8691.2010.00547.x

De Jong, J. P., \& Den Hartog, D. N. (2008). Innovative work behavior: Measurement and validation. EIM Business and Policy Research, 8(1), 1-27. Access address: http://ondernemerschap.panteia.nl/pdfez/h200820.pdf

De Jong, J.P. (2006), The decision to innovate, literature and propositions. Scales-Initiative Report, 5-38. Access address: https://ideas.repec.org/p/eim/papers/h200607.html

Dictionary of Business (2002). Oxford business dictionary, Third Edition, New York: Oxford University Press.

Drucker, P.F. (1998) The discipline of innovation. Harvard Business Review, 76(6), 149-157. https://doi.org/10.1002/lt1.40619980906

Engelen, A., Weinekötter, L., Saeed, S., \& Enke, S. (2018). The effect of corporate support programs on employees' innovative behavior: a cross-cultural study. Journal of Product Innovation Management, 35(2), 230-253. https://doi.org/10.1111/jpim.12386

Eren, S. S., \& Hayatoğlu, Ö. (2011). Etik iklimin satış elemanlarının iş tutumlarına ve iş performanslarına etkisi: İlaç sektöründe bir uygulama (The Effect Of Ethical Climate On Salesperson's Job Attitudes, And Job Performance: An Application In Pharmaceutical Sector). Uluslararası Yönetim İktisat ve İsletme Dergisi, 7(14), 109-128. Access address: https://dergipark.org.tr/tr/download/article-file/1145941

Eyidoğan, Ö. (2013). Etik iklimin örgütsel iletişim üzerindeki etkisi (The impact of ethical climate on organizational communication). (Unpublished master's thesis), Marmara Üniversitesi, İstanbul. Access address: https://tez.yok.gov.tr/

Hair, J. F., Black, W. C., Babin, B. J., Anderson, R. E. \& Tatham, R. L. (2013). Multivariate data analysis, New Jersey: Pearson Education.

Hrnjic, A., Pilav-Velic, A., Djidelija, I., \& Jahic, H. (2018). Innovative Behavior and Employee Job Satisfaction in Telecommunications Sector. Economic Review: Journal of Economics and Business, 16(1), 19-30. Access address: https://www.econstor.eu/bitstream/10419/193880/1/econ-review-v16-i1-p019-030.pdf

Janssen, O. (2000). Job demands, perceptions of effort-reward fairness and innovative work behaviour. Journal of Occupational and Organizational Psychology, 73(3), 287-302. https://doi.org/10.1348/096317900167038

Kalaycı, Ş., (2008), SPSS Uygulamalı Çok Değişkenli İstatistik Teknikleri (SPSS Applied Multivariate Statistics Techniques). (3.Baskı). Ankara: Asil Yayın Dağıtım.

Kanter, R. M. (1988). When a thousand flowers bloom: Structural, collective, and social conditions for innovation in organizations. Knowledge Management and Organisational Design, 10, 93-131. https://doi.org/10.1016/B978-0-7506-9749-1.50010-7

Karadut, G. (2014). Etik iklimin ve örgütsel adalet algılarının çalışanların iş tatminine etkisi: konaklama işletmelerinde ampirik bir uygulama (The effect of ethical climate and organisational justice on employees' job satisfaction: An empirical study in hospitality sector). (Unpublished master's thesis), Bahçeşehir Üniversitesi, İstanbul. Access address: https://tez.yok.gov.tr/ 
Kılıç, R., \& Keklik, B. (2012). Kobi’lerde genel firma özelliklerinin inovasyon uygulamalarına etkisi: Balıkesir ilinde bir araştırma (The Effect Of General Firm Specialities On Innovation Applications In Sme's:A Research In Balikesir). Erciyes Üniversitesi İktisadi ve İdari Bilimler Fakültesi Dergisi, 39, 93-118. Access address: http://iibf.erciyes.edu.tr/dergi/sayi39/ERUJFEAS_Jan2012_93to118.pdf

Kökalan, Ö., \& Şevik, Ü. (2019). The effects of perceived organisational justice and ethical climate on job satisfaction, turnover intention and job performance. Middle East Journal of Management, 6(4), 436450. https://doi.org/10.1504/MEJM.2019.100815

Lukes, M., \& Stephan, U. (2017). Measuring employee innovation: a review of existing scales and the development of the innovative behavior and innovation support inventories across cultures. International Journal of Entrepreneurial Behavior \& Research, 23(1), 136-158. https://doi.org/10.1108/IJEBR-11-2015-0262

Martin, K. D., \& Cullen, J. B. (2006). Continuities and extensions of ethical climate theory: A meta-analytic review. Journal of Business Ethics, 69(2), 175-194. https://doi.org/10.1007/s10551-006-9084-7

Neubaum, D., Mitchell, M., \& Schminke, M. (2004). Firm newness, entrepreneurial orientation, and ethical climate. Journal of Business Ethics, 52(4), 335-347. https://doi.org/10.1007/s10551-004-1532-7

Ögüt, A., \& Kaplan, M. (2011). Otel işletmelerinde etiksel iklim algılamaları ile örgütsel bağlılık arasındaki ilişkinin analizi: Kapadokya örneği (The Relationship Between Perceptions Of Ethical Climate Types And Organizational Commitment In Hotel Businesses: The Case of Cappadocia) Dumlupinar Üniversitesi Sosyal Bilimler Dergisi, 30, 191-206. Access address: https://tez.yok.gov.tr/

Öztürk, E. (2006). Çoklu Doğrusal Regresyon Modeli (Multiple Linear Regression Model) Ş.Kalaycı (Ed). SPSS Uygulamalı Çok Değiş̧kenli İstatistik Teknikleri (SPSS Applied Multivariate Statistics Techniques) içinde. Ankara: Asil Yayın Dağıtım.

Özyer, K. (2010). Etik iklim ve işten ayrılma niyeti arasındaki ilişkide örgütsel bağlllık ve iş tatmininin düzenleyici rolü (The moderator role of organizational commitment and job satisfaction upon the relation between ethical climate and turnover intention). (Unpublished doctoral dissertation), Hacettepe Üniversitesi, Ankara. Access address: https://tez.yok.gov.tr/

Radaelli, G., Lettieri, E., Mura, M. \& Spiller, N. (2014). Knowledge sharing and innovative work behaviour in healthcare: a micro-level investigation of direct and indirect effects. Creativity and Innovation Management, 23(4), 400-414. https://doi.org/10.1111/caim.12084

Ramamoorthy, N., Flood, P. C., Slattery, T., \& Sardessai, R. (2005). Determinants of innovative work behaviour: Development and test of an integrated model. Creativity and Innovation Management, 14(2), 142-150. https://doi.org/10.1111/j.1467-8691.2005.00334.x

Sabuncuoğlu, Z. (2009). Turizm işletmelerinde örgütsel davranış (Organizational behavior in tourism businesses). Bursa: MKM Yayınları.

Scott, S. G. \& Bruce, R. A. (1994). Determinants of innovative behavior: A path model of individual innovation in the workplace. Academy of Management Journal, 37(3), 580-607. https://doi.org/10.2307/256701

Sökmen, A. (2016). Meslek etiği (örgütsel ve yönetsel etik kurumsal sosyal sorumluluk) (Professional ethics: Organizational and managerial ethics, corporate social responsibility). Ankara: Detay Yayıncilık.

Tekin, İ. Ç., \& Akgemci, T. (2019). Örgütsel bağlılı̆̆ın yenilikçi iş davranışına etkisi. (The Effect of Organizational Commitment On Innovative Work Behaviour) Business \& Management Studies: An International Journal, 7(4), 1709-1739. https://doi.org/10.15295/bmij.v7i4.1189 
Torun, M.K. (2013). Turizm alanında lisans ve önlisans eğitimi veren kurumlarda etik iklimin kuruma güven üzerindeki etkisi (The effect of ethical climate on organizational trust in institutions training graduate and undergraduate education). (Unpublished master's thesis), Düzce Üniversitesi, Düzce. Access address: https://tez.yok.gov.tr/

Tsalikis, J., \& Fritzsche, D. J. (2013). Business ethics: A literature review with a focus on marketing ethics. In Citation Classics from the Journal of Business Ethics, Ed. Michalos A. C.\& Deborah C. P. (337-404). Dordrecht: Springer. https://doi.org/10.1007/978-94-007-4126-3_17

Tütüncü, Ö. ve Savran, G. (2007). Etik iklim ve tükenmişlik sendromunun kalite yönetim sistemi üzerine etkileri: Bir laboratuar uygulaması (Quality Of Ethical Climate And Burnout Syndrome Syndrome Effects On The Management System: One Laboratory Application). Dokuz Eylül Üniversitesi Sosyal Bilimler Enstitüsü Dergisi, 9(4), 177-218. Access address: http://hdl.handle.net/20.500.12397/5577

Ungureanu, M., Pop, N., \& Ungureanu, N. (2016). Innovation and technology transfer for business development. Procedia Engineering, 149, 495-500. https://doi.org/10.1016/j.proeng.2016.06.697

Unsworth, K. L., \& Parker, S. K. (2003). Proactivity and innovation: Promoting a new workforce for the new workplace. The new workplace: A guide to the human impact of modern working practices, in Holman, T., Wall, T. D., Clegg, C. W., Sparrow, P. \& Howard, A. (Eds), The new workplace: A guide to the human impact of modern work practices, s. 175-196. Chichester: Wiley. https://doi.org/10.1002/9780470713365.ch10

Van de Ven, A. H. (1986). Central problems in the management of innovation. Management Science, 32(5), 590-607. https://doi.org/10.1287/mnsc.32.5.590

Victor, B., \& Cullen, J. B. (1988). The organizational bases of ethical work climates. Administrative Science Quarterly, 101-125. https://doi.org/10.2307/2392857

West, M. A. (2002). Sparkling fountains or stagnant ponds: An integrative model of creativity and innovation implementation in work groups. Applied Psychology, 51(3), 355-387. https://doi.org/10.1111/14640597.00951

West, M. A., \& Anderson, N. R. (1996). Innovation in top management teams. Journal of Applied Psychology, 81(6), 680-693. https://doi.org/10.1037/0021-9010.81.6.680

West, M. A., \& Wallace, M. (1991). Innovation in health care teams. European Journal of Social Psychology, 21(4), 303-315. https://doi.org/10.1002/ejsp.2420210404

Wojtczuk-Turek, A. (2012). Innovative work behavior and psychological capital-analysis of relationships. Organizacja i Zarzadzanie: Kwartalnik Naukowy, 3(19), 71-88. Access address: http://oamquarterly.polsl.pl/wp-content/uploads/2018/01/05-Wojtczuk-Turek-KN19.pdf

Yağmur, A. (2013). Etik liderlĭğin ve etik iklimin etik dışı davranışlara etkisi: Ampirik bir çalışma (The effects of ethical leadership and ethical climate on unethical behaviors: An empirical study). (Unpublished master’s thesis), Gebze Yüksek Teknoloji Enstitüsü, Kocaeli. Access address: https://tez.yok.gov.tr/

Yeşil, S., Mavi, Y., \& Ceylan, S. (2017). Etik iklim algısı ve bireysel sonuçlar üzerine etkileri (The Perception of Ethical Climate And Its Effects On Individual Results). Dumlupınar Üniversitesi Sosyal Bilimler Dergisi, 51, 19-38. Access address: https://dergipark.org.tr/en/download/article-file/279307

Yurdakul, M. (2013). İş ahlakında etik iklim: bireysel ve kurumsal özellikler açısından etik iklimin bankacılık sektöründe araştırılması (Ethical climate in business ethics: Research on ethical climate in banking sector regarding individual and institutional characteristics). (Unpublished master's thesis), İstanbul Üniversitesi, İstanbul. Access address: https://tez.yok.gov.tr/ 